\title{
NOT MY DOCTRINE? FINDING A CONTRACT LAW EXPLANATION FOR NON EST FACTUM
}

\author{
Simon Connell*
}

\begin{abstract}
Non est factum (Latin for "not my deed") is a common law doctrine that can allow the signer of a legal document to escape the usual legal consequences of their signature. In its early days, non est factum was available only to blind and illiterate persons who, without being careless, relied on another party's seriously flawed explanation of the document. Non est factum can void contracts, but I argue the general explanation for the doctrine is not a satisfactory explanation for why it applies to contracts. This article considers whether there is an explanation for non est factum that is consistent with contract law thinking. I argue that there is, and explain non est factum as an application of the objective principle set out in Smith v Hughes.
\end{abstract}

\section{INTRODUCTION}

This introductory part briefly explains why one might question the place of non est factum in contract law and sets out the theoretical framework and structure of this article.

\section{A Why Question the Place of Non Est Factum in Contract Law?}

Non est factum is available to a signer who, without carelessness, signed a document on the basis of a fundamentally incorrect explanation of the document's contents given by someone else, whom I shall refer to as the "explainer". ${ }^{1}$ A successful plea $^{2}$ of non est factum means that the document is void. As a result, no one else can enforce it. The requirements for a successful plea are generally presented as a series of assessments to be made of the signer - the enforcer does not feature. This is an anomaly among contract law doctrines that address disputes where one party

* Lecturer, Faculty of Law, University of Otago. I wish to acknowledge the valuable research assistance of Sam Cathro.

1 This description will suffice for now, but I will discuss the requirements further below at Part II: Features of Non Est Factum.

2 Non est factum can be described as a doctrine in the sense that it is part of the law, or as a plea in the sense of an attempt by a particular signer to invoke the doctrine. 
seeks relief from a mistake in some sense or on the basis that they did not truly consent. Under such circumstances, contract law is normally concerned with the enforcer as well as the signer, as illustrated in the following table. ${ }^{3}$

\begin{tabular}{|c|c|c|}
\hline & $\begin{array}{l}\text { Assessment with respect to } \\
\text { the signer }\end{array}$ & $\begin{array}{l}\text { Assessment with respect to } \\
\text { the enforcer }\end{array}$ \\
\hline Duress & Was the signer under duress? & $\begin{array}{l}\text { Did the enforcer place the } \\
\text { signer under duress? }\end{array}$ \\
\hline Undue Influence & $\begin{array}{l}\text { Was the signer unduly } \\
\text { influenced? }\end{array}$ & $\begin{array}{l}\text { Was the enforcer an undue } \\
\text { influencer, or ought the } \\
\text { enforcer have taken steps to } \\
\text { protect against undue } \\
\text { influence and failed to do so? }\end{array}$ \\
\hline Misrepresentation & $\begin{array}{l}\text { Was the signer induced to enter } \\
\text { into the contract by a } \\
\text { misrepresentation? }\end{array}$ & $\begin{array}{l}\text { Was the misrepresentation } \\
\text { made by or on behalf of the } \\
\text { enforcer? }\end{array}$ \\
\hline Unilateral mistake & $\begin{array}{l}\text { Did the signer make a } \\
\text { qualifying mistake? }\end{array}$ & $\begin{array}{l}\text { Did the enforcer actually know } \\
\text { of the signer's mistake? }\end{array}$ \\
\hline Common mistake & \multicolumn{2}{|c|}{$\begin{array}{l}\text { Were the signer and enforcer both influenced by the same } \\
\text { qualifying mistake? }\end{array}$} \\
\hline Rectification & \multicolumn{2}{|c|}{$\begin{array}{l}\text { Did the signer and enforcer actually intend the same thing for } \\
\text { their contract but, by mistake, the written document does not } \\
\text { reflect that shared intention? }\end{array}$} \\
\hline Unconscionable Bargain & $\begin{array}{l}\text { Was the signer suffering under } \\
\text { a disability? }\end{array}$ & $\begin{array}{l}\text { Did the enforcer have actual or } \\
\text { constructive knowledge of that } \\
\text { disability? }\end{array}$ \\
\hline \multicolumn{3}{|l|}{ Compare with: } \\
\hline Non Est Factum & $\begin{array}{l}\text { Did the signer sign the } \\
\text { document without carelessness, } \\
\text { upon the basis of an explainer's } \\
\text { fundamentally incorrect } \\
\text { explanation? }\end{array}$ & Nil \\
\hline
\end{tabular}

The general theme here is that the signer's claim for relief will only succeed if the enforcer is a part of, knew of (or ought to have known of), or is responsible for, the mistake or vitiated consent. Non est factum is not typically explained as involving that kind of assessment of the enforcer.

The presentation of non est factum as an apparently unilateral inquiry raises the possibility that the doctrine is best understood as a common law doctrine that happens to apply to contracts, albeit

3 This table is not intended as a comprehensive summary of the law involved but rather serves to highlight the unusual unilateral nature of the typical presentation of the requirements for non est factum. 
in a way that is inconsistent with contract law. ${ }^{4}$ The alternative is that non est factum can, upon closer examination, be understood as being consistent with contract law.

\section{B Theoretical Framework}

To conclude that non est factum can be understood as being consistent with contract law requires identifying a contract law explanation for the doctrine. By an explanation, I mean an exposition of the underlying rationale for the doctrine. ${ }^{5}$ By a contract law explanation, I mean an explanation that is consistent with the doctrines of contract law and with the kinds of explanations for contract law doctrines typically put forward by contract law thinkers. ${ }^{6}$ The ideal contract law explanation for non est factum would:

(1) provide an explanation for why non est factum applies to contracts; ${ }^{7}$

(2) be consistent with contract law generally; ${ }^{8}$

(3) be consistent with contract law thinking; ${ }^{9}$ and

(4) explain the specific features of the doctrine. ${ }^{10}$

4 Thus "not my doctrine".

5 For example, one could say that the rationale for the doctrine of frustration is that it gives effect to an implied term that the contract would come to an end under certain circumstances: Taylor v Caldwell (1863) 3 B\&S 826, 122 ER 309 (QB) at 313. Alternatively, one could suggest that the doctrine of frustration exists because justice demands that courts sometimes make an exception to the general rule of absolute contracts and relieve parties from their obligations, regardless of the parties' actual intentions: Hirji Mulji $v$ Cheong Yue Steamship Co Ltd [1926] AC 497 (PC) at 510.

6 My search for a contract law explanation is a piece of interpretive rather than historical analysis. That is, I am not concerned with what the judges involved in developing non est factum actually had in mind (that would be historical analysis). Rather, I am concerned with, as Beever and Rickett put it, "how the law as it exists now should be understood": Allan Beever and Charles Rickett "Interpretive Legal Theory and the Academic Lawyer" (2005) 68 MLR 320 at 324. Interpretive accounts seek to explain the state of the law on the basis that the law is governed by underlying intelligible norms. In this article, I am seeking an explanation for non est factum that is consistent with the established norms of contract law. See Stephen A Smith Contract Theory (Oxford University Press, Oxford, 2004) for further exposition of interpretive, as opposed to historical, prescriptive or descriptive analysis.

7 For example an explanation that only provided a rationale for why non est factum applied to deeds would fail to meet this criterion.

8 An explanation based on a rationale that, if taken seriously, would produce results that conflict with the substance of contract law would fail to meet this criterion.

9 An explanation that gave a rationale for why non est factum applied to contracts would fail to meet this criterion if the rationale was incompatible with the sorts of rationales we normally find in contract law thinking. This criterion follows from taking an interpretive approach: see above $\mathrm{n} 6$.

10 The ideal contract law explanation would not only be consistent with the substance of contract law generally (criterion 2), but would also explain the specific requirements of non est factum (the need for an erroneous explanation and so on). 
The search for a contract law explanation for non est factum is not a purely academic exercise. If non est factum can be understood as a contract law doctrine, ${ }^{11}$ then we can turn to contract law thinking to help resolve any questions about what is required to make out a successful plea, both in terms of how the requirements of the doctrine are formulated in the abstract and whether or not the doctrine is available on a specific set of facts. If not, then we should be content that non est factum produces results that are inconsistent with contract law, because there is no reason to expect otherwise.

\section{Structure of this Article}

Part II of this article is focused on providing a descriptive account of the current state of non est factum, with some discussion of the history of how the doctrine evolved to that point. Part III shifts to interpretive analysis. In Part III, I first set out the traditional explanations for the doctrine, which I then argue do not explain why non est factum applies to contracts. Then, I move to consideration of a contract law explanation for non est factum. I am aware of one developed attempt at a contract law explanation for non est factum, that of Mindy Chen-Wishart. After setting out her explanation, I critique it, finding it wanting in terms of explaining the specific features of the doctrine. Finally, I go on to set out my own contract law explanation of non est factum, which is that non est factum can be understood as a particular instance of the objective approach to contract formation set out in Smith $v$ Hughes. ${ }^{12}$

\section{FEATURES OF NON EST FACTUM}

There are three main features of the doctrine of non est factum: it is restricted to certain persons and documents; it requires a fundamentally incorrect explanation; and the signer must not have been careless. The primary source for the account of the present state of non est factum is the seminal case of Saunders v Anglia Building Society Ltd, also known as Gallie v Lee and referred to herein as Saunders. ${ }^{13}$ This was a 1971 case where the House of Lords took the opportunity to clean up some messy historical baggage that the doctrine had accumulated and provide a modern restatement of the doctrine.

\section{A Available to Whom and Applies to What}

Non est factum was originally available only in relation to deeds, and only to a signer who could establish that they had not physically executed the deed. ${ }^{14}$ Such a signer could claim literally that the deed was "not my deed". The signature was of no effect and the deed void and accordingly

11 At least when it is applied as between contracting parties.

12 Smith v Hughes (1871) LR 6 QB 597, [1861-73] All ER 632 (QB).

13 Saunders v Anglia Building Society Ltd [1971] AC 1004 (HL).

14 See the judgment of Salmon LJ in Gallie v Lee [1969] 2 Ch 17 (CA) at 42-43 for a discussion of this history. 
unenforceable by any other party who sought to rely on it. The set of people who could successfully plead non est factum has been widened a number of times since then.

The first major expansion of non est factum occurred at a time when a large proportion of the population was unable to read, and transactions involving deeds were commonplace. The plea was extended to blind and illiterate persons who had relied on someone else's explanation of the deed. ${ }^{15}$ Recognising that the expansion of non est factum potentially undermined the ability of parties to rely on signed legal documents generally, and for contracting parties to rely on signed written contracts, courts sought to limit its scope. This was done by developing the other two features of non est factum that I will set out in more detail shortly: not just any inaccuracy in the explanation will suffice; and the signer must not have been careless.

In the 19th century, non est factum was extended to cover written contracts as well as deeds. ${ }^{16} \mathrm{It}$ was also held to be available to literate persons who had not acted carelessly. ${ }^{17}$ The case law and literature is not entirely clear about the precise circumstances under which non est factum is available to literate persons. There is some suggestion that some kind of incapacity with respect to understanding the document is still required, even if it falls short of outright inability to read. ${ }^{18}$ Some sources suggest having been tricked as an alternative to establishing the aforementioned

15 Thoroughgood's Case (1582) 2 Co Rep 9, 76 ER 408 (Comm Pleas).

16 Foster v Mackinnon (1869) LR 4 CP 704 (QB) at 712.

17 At 711, where Byles J states that non est factum was available to "a blind man, or a man who cannot read, or who for some reason (not implying negligence) forbears to read" (emphasis added).

18 In Saunders, above n 13, at 1016, Lord Reid at stated that the extension of non est factum to the blind and illiterate logically should also apply to:

... those who are permanently or temporarily unable through no fault of their own to have without explanation any real understanding of the purport of a particular document, whether that be from defective education, illness or innate incapacity.

However, after stressing the need for such persons to take reasonable care, he went on to say at 1016 :

I do not say that the remedy can never be available to a man of full capacity. But that could only be in very exceptional circumstances: certainly not where his reason for not scrutinising the document before signing it was that he was too busy or too lazy. In general I do not think he can be heard to say that he signed in reliance on someone he trusted. But, particularly when he was led to believe that the document which he signed was not one which affected his legal rights, there may be cases where this plea can properly be applied in favour of a man of full capacity.

The High Court of Australia stated in Petelin v Cullen (1975) 132 CLR 355 at [12] that non est factum is limited to:

... those who are unable to read owing to blindness or illiteracy and who must rely on others for advice as to what they are signing [and] those who through no fault of their own are unable to have any understanding of the purport of a particular document. 
incapacity. ${ }^{19}$ Alternatively, some cases appear to take the approach that there is no discrete requirement for incapacity or trickery, but that the signer's capacity and the presence of trickery may be relevant when considering if the signer was careless. ${ }^{20}$

\section{B Fundamentally Incorrect Explanation}

Non est factum is only available when the document in question is fundamentally different in effect to what the signer thought because of the explainer's incorrect explanation. In Saunders, their Lordships use wording such as "radical", "essential", "fundamental" or "very substantial".21 Saunders sensibly did away with a confusing and difficult to justify line of cases that held that the difference in question had to go to the character of the document rather than merely its contents. ${ }^{22}$

19 This appears to stem from Lord Wilberforce's comments in Saunders, above n 13, at 1025, that while non est factum should be denied to "a man of full understanding and capacity [who] forbears, or negligently omits, to read what he has signed", there was a "residue of difficult cases" including "illiterate or senile persons who cannot read, or apprehend, a legal document" and "persons who may be tricked into putting their signature on a piece of paper which has legal consequences totally different from anything they intended". For examples of this "incapacity or trickery" account of to whom non est factum is available see H G Beale "Mistake as to the Terms or as to Identity" in HG Beale and others Chitty on Contracts (32nd ed, Sweet \& Maxwell, London, 2015) 339 at [3-055]; Ewan McKendrick "Contract: In General" in Andrew Burrows (ed) English Private Law (3rd ed, Oxford University Press, Oxford, 2013) 481 at [8.150]; and Mindy Chen-Wishart "Contractual Mistake, Intention in Formation and Vitiation: the Oxymoron of Smith $v$ Hughes" in Jason W Neyers, Richard Bronaugh and Stephen GA Pitel (eds) Exploring Contract Law (Hart Publishing, Oxford, 2009) 341 at 364.

20 This is consistent with Viscount Dilhorne's statement in Saunders, above n 13, at 1023:

Is it possible to define what will amount to a lack of care in the signing of a document? ... I do not think it can be said that in every case failure to read a document by a literate person amounts to carelessness. Should the same standard of care be expected of an elderly spinster who might, if she read the document, be none the wiser and who might not be able to distinguish between a mortgage and a conveyance? I am inclined to think not.

As an example of an exposition of the requirements for non est factum that does not refer to incapacity or trickery, see the New Zealand case of Bradley West Solicitors Nominee Co Ltd v Keeman [1994] 2 NZLR 111 (HC) (recently applied in Radius Residential Care Ltd v Krishna [2013] NZHC 2886, where the defendant succeeded on a plea of non est factum), where Tipping $\mathbf{J}$ sets out the requirements for non est factum at 120-121, followed by a statement that the signer is assumed to be "male and of full age and contractual capacity". For a further example of an exposition of non est factum without reference to incapacity or trickery, see the pithy statement by Judge Anthony Thornton QC in Trustees of Beardsley Theobalds Retirement Benefit Scheme v Yardley [2011] EWHC 1380 (QB) at [53]:

Non est factum is a shorthand way of saying that a person is not bound by a deed he has signed if he made a fundamental mistake as to the nature of the transaction and had taken all reasonable precautions available to him before signing to ascertain the nature and purpose of the deed being signed.

21 Saunders, above n 13, at 1017, 1022 and 1026.

22 Howatson $v$ Webb [1908] 1 Ch 1 (CA). 


\section{Signer Must Not Have Been Careless}

Non est factum is available only to a signer who has not been careless, and it is up to the signer to prove that they have not been careless. ${ }^{23}$ It is now clear that the kind of carelessness under consideration in non est factum is not the same as that of a breach of a tortious duty to take care. ${ }^{24}$

\section{EXPLAINING NON EST FACTUM \\ A Traditional Explanations for Non Est Factum}

The case law features two main explanations for why the doctrine of non est factum operates in the way that it does. The first is what I will call the consent explanation of non est factum. It is illustrated in Byle J's oft-cited statement in Foster $v$ Mackinnon that, when the doctrine of non est factum applies, the signature is of no force: ${ }^{25}$

... not merely on the ground of fraud, where fraud exists, but on the ground that the mind of the signer did not accompany the signature; in other words, that he never intended to sign, and therefore in contemplation of law never did sign, the contract to which his name is appended.

The second is what I will call the compromise explanation, which is the idea articulated by Lord Wilberforce in Saunders that non est factum strikes a balance between two competing policy objectives:

- the protection of innocent third parties who rely on the validity of apparently legitimate signed legal documents; and

- the desire to provide relief to signers who did not actually consent to documents that they signed. ${ }^{26}$

23 Saunders, above n 13, at 1019.

24 Saunders, above n 13; and Petelin v Cullen, above n 18.

25 Foster v Mackinnon, above n 16, at 711 (emphasis added). It is cited for example in Saunders, above n 13, at 1026, where Lord Wilberforce endorses this explanation, and at 1016, where Lord Reid states that the consent explanation features in many of the authorities.

26 Saunders, above n 13, at 1023. See also Petelin $v$ Cullen, above n 18, at [11], wording the first policy objective as being that a person should not be held "to a bargain to which he has not brought a consenting mind". Compare Bradley West, above n 20, at 118, where Tipping J explains non est factum as a compromise between the protection of "parties who have acted on the faith of an apparently valid instrument from too easy a disavowal by a signatory of the binding force of his signature" and "the law's increasing focus on consensus in contract". For an example of the compromise explanation in the academic writing on the doctrine, see Charles YC Chew "The Application of the Defence of Non Est Factum: An Exploration of its Limits and Boundaries" (2009) 13 UWSLR 83 at 99: "The rationale and policy considerations leading to this pattern [of stringent tests for the defence] are founded on (i) the balancing of the rights of innocent third parties against (ii) the injustice of holding guarantors to contracts to which they did not bring a consenting mind." Chew's articulation of the latter policy follows from the article's focus on evaluating the limits and breadth of non est factum as applied to contracts of guarantee. 


\section{B The Traditional Explanation is a Poor Fit for Contract Law}

\section{The problem with the consent explanation}

The traditional explanations for non est factum fall far short in terms of providing a contract law explanation for non est factum. First of all, as Lord Reid in Saunders ${ }^{27}$ and Chen-Wishart ${ }^{28}$ point out, the consent explanation of non est factum is overinclusive. Contract law does not now find, and never has found, one party's lack of consent sufficient to justify a conclusion that there is no contract. The consent explanation of non est factum is, without more, incompatible with the objective assessment of intentions that is a key feature of contract law. Indeed, the potential danger of conflicting with the objective principle is one of the drives for the restrictive approach courts have taken when non est factum is available. ${ }^{29}$ The consent explanation thus fails because its principled basis is incompatible with contract law doctrine and thinking. Furthermore, it fails to explain the specific restrictions placed on the plea of non est factum.

\section{The problem with the compromise explanation}

The idea that non est factum is best understood as a compromise between two competing policy objectives is an improvement on the consent explanation. The compromise explanation can be seen as taking the consent explanation as a starting point, but then weighing up the regard for individual consent with a regard for innocent third parties. That non est factum is a balance between competing policy objectives could, unlike the consent explanation, explain why non est factum is limited in the way that it is. However, the policy compromise set out in the compromise explanation is a poor fit for explaining why non est factum applies to contracts. This is because, I will argue, contracting parties are so different from innocent third parties that accepting the policy that we should protect innocent third parties gives us neither (i) a reason for why contracting parties should also be protected nor (ii) a reason to think that the doctrine of non est factum should be the mechanism used to provide that protection. There are three parts to this argument. First, I will give an example of an innocent third party. Secondly, I will identify several ways in which contracting parties differ from innocent third parties: contracting parties have a stronger moral and a different legal claim to enforcement, and they interact with the signer and are responsible for the document in ways that innocent third parties are not. Thirdly, I will make the case as to why those differences are significant. Ultimately, what I am seeking to establish in that three-part argument is not that there is no good explanation for why non est factum applies to contracts and why the doctrine has the features that it does, but that the compromise explanation is not such an explanation.

27 Saunders, above n 13, at 1016.

28 Chen-Wishart, above n 19, at 364.

29 McKendrick, above n 19, at [8.149]. 


\section{Example of an innocent third party: The Anglia Building Society}

For an example of such an innocent third party, let us turn to the facts of Saunders. A widow Gallie, with the intention of providing financial assistance to her nephew Parkin, executed an assignment of her house to a Mr Lee, an associate of Parkin, for the sum of $£ 3,000$ (though Gallie never received the money). ${ }^{30}$ At the time she signed the deed, her spectacles were broken and she relied on Lee's incorrect explanation that the effect of the document was that she was gifting the house to Parkin and that she could live there for the rest of her life. On the strength of the deed showing his interest in the house, Lee mortgaged the property to the Anglia Building Society. After Lee defaulted on his mortgage obligations, the Society sought to obtain possession of the house, which Gallie sought to resist upon the basis of non est factum.

Discussions of the case typically focus on Gallie and her conduct, but let us for a moment consider the Building Society. The Society was arguably a true innocent third party. The Society was a third party to the interactions between Gallie, Lee and Parkin that led to Gallie signing a document based on a false impression. Neither Parkin nor Lee were agents of the Society, and there is no sense in which the Society could be said to be responsible for their collective misconduct towards Gallie. Indeed, the false explanation occurred before the Society lent money to Lee. The Society was innocent in the sense that they had no actual or constructive knowledge that something might have been awry in the transaction between Gallie and Lee. If non est factum were to apply, then the assignment would be void and accordingly unenforceable by the Society - giving effect to Gallie's actual intentions would result in an innocent third party missing out. The Society is thus an illustrative example of the sort of innocent third parties that the compromise explanation is concerned with protecting. Indeed, the Society was protected by the courts. The House of Lords, like the Court of Appeal $^{31}$ before them, found that Gallie failed to establish her plea of non est factum. Her case was lacking both in terms of the document not being radically different from what she thought ${ }^{32}$ and because she had been careless. As Viscount Dilhorne put it, Gallie: ${ }^{33}$

... was content to trust her nephew and Lee and, sad though it is that an old lady should suffer as a result of the misconduct by Lee, she cannot relieve herself of the consequences at the expense of the respondents who advanced money on the faith of the document.

In the case where the signer has signed a contract with the enforcer, the enforcer is in a very different position compared with an innocent third party like the Society. Let me explain how.

30 Strictly, Gallie owned a low-rent long-term lease on the house, effectively making her the owner.

31 Gallie v Lee, above n 14.

32 Whether the document was a gift to Lee or assignment to Parkin, the consequence for Gallie was essentially the same: she gave up her interest in the property for the purpose of benefitting Lee.

33 Saunders, above n 13, at 1020. 


\section{Contracting party enforcers have a stronger moral claim}

First of all, as between the signer and the enforcer, a contracting party enforcer has a stronger moral claim to the performance of the contract compared to a third party. ${ }^{34}$ The third party's claim to performance is based on the general expectation that signed legal documents are enforceable. A contracting party's claim is not simply based on that general expectation but rather is based on the contractual relationship that they have reason to believe exists between them and the signer. By seeking to enter into a contractual relationship, a contracting party has sought to exchange legal obligations with the signer. This exchange of legal obligations gives a contracting party enforcer a claim to the signer's performance over and above the general expectation that signed legal documents are enforceable.

In this context, there are two different ways we can conceptualise the exchange represented by a contract. The first is by turning to the doctrine of consideration, which can be understood as the idea that a contract is the exchange of promises to perform. At an abstract level, each party's promise to perform their side of the bargain is made in exchange for the other party's corresponding promise. As Ernest Weinrib puts it: ${ }^{35}$

Under the doctrine of consideration, a promise is contractually binding only if the promisee has promised or done something in return. The principal function of this doctrine is to capture the bipolarity of the contractual relationship by affirming the promisee's participation in creating the right to the promisor's performance. The doctrine also reflects the unity of the parties' relationship: promise and consideration are not bounties unilaterally volunteered to each other; rather, the consideration is something that the parties understand to be given in return for the promise.

The second way we can conceptualise a contract as an exchange is with reference to objectivity. In the abstract, contracting parties can be seen as exchanging the obligation to be bound to perform the objective meaning of the contract for the right to the other party's performance of the objective meaning of the contract. Upon entering a contract, a contracting party takes on the risk that the meaning that they believe the contract to have is not actually the objective meaning of the contract, which is the meaning that the law will enforce in the case of a dispute. There are several reasons why this risk is justifiable for a contracting party. First of all, the risk is taken on in exchange for the other contracting party adopting the reciprocal risk. Secondly, reasonableness is an intrinsic part of objectivity in contract law, so a party who turns out to be wrong about the objective meaning of the contract is, at worst, bound to what a reasonable person would think they are bound. To recap, these

34 For the avoidance of doubt, by "contracting party enforcer", I mean a party seeking to enforce a signed document on the basis that the document is a contract between the signer and the enforcer. The signer, of course, might argue that there is no contract.

35 Ernest J Weinrib The Idea of Private Law (Harvard University Press, Cambridge (Mass), 1995) at 137-138. 
two understandings of contract as exchange, which apply concurrently, can be summarised as follows.

\begin{tabular}{|l|l|l|}
\hline Conceptualisation & Signer & Enforcer \\
\hline Consideration-based & $\begin{array}{l}\text { Each party promises to perform in exchange for the other's } \\
\text { reciprocal performance. }\end{array}$ \\
\hline Objectivity & $\begin{array}{l}\text { Each party agrees to be bound by objective contract } \\
\text { formation and construction, even if that results in a contract } \\
\text { other than what they actually intended, on the basis that the } \\
\text { other party takes on the same obligation. }\end{array}$ \\
\hline
\end{tabular}

These two conceptualisations of contracts as exchange give a contracting party enforcer a stronger moral claim to performance than a third party enforcer. The contracting party enforcer's claim is stronger because they have given something up and taken a risk for the right to the signer's performance. Of course, a third party may also have given something up with respect to the deed in question. The Society in Saunders lent money to Parkin. However, the critical difference is that a contracting party has given something up to the signer in exchange for the right to the signer's performance. With respect to the enforcer, even if we are to see a signed deed as a kind of promise to be bound by the document, then it is a gratuitous promise with respect to the enforcer as opposed to the mutual promises of a contract. This gives a contracting party enforcer's claim to expect the signer's performance an entirely different moral quality to a third party enforcer's. A contract is a unique legal relationship that carries with it a unique moral force. ${ }^{36}$

\section{Contracting party enforcers have a different legal claim}

As well as having a morally stronger claim to expect the signer's performance, I would note that a contracting party enforcer can also make a legal claim that a third party enforcer cannot. If a signer refuses to do what the document says on the basis that they did not actually intend it, then the contracting party can argue that this is a breach of a contractual obligation. The consequence of this is that a contracting party enforcer can access contract law remedies not available to a third party enforcer. Probably the most significant types of contract law remedies available to a contracting party enforcer but not a third party enforcer are expectation damages and remedies for cancellation.

\section{Contracting party enforcers interact with the signer}

A third party enforcer may have had no contact whatsoever with the signer up until the point where they seek to enforce the deed. In contrast, for a contract to have arisen, a contracting party

36 As Peter Benson put it, the doctrine of consideration "establishes a form and content of relation that is irreducibly different from those entailed by either estoppel or a seal": Peter Benson "The Idea of Consideration" (2011) 61 UTLJ 241 at 278. 
enforcer must necessarily have had some interaction with the signer. At a minimum, the signer has signed the enforcer's offer. In some cases, there will have been communication and negotiation between the enforcer and the signer. That minimal interaction means that the enforcer has had at least a brief opportunity to make an assessment of the signer's circumstances before the document is signed. That will often not be the case with third party enforcers, for example in the Saunders case, where Lee had obtained the deed from Gallie prior to approaching the Society for a loan.

\section{Contract party enforcers are responsible for the document}

In third party enforcer cases, the enforcer will often be seeking to enforce a deed that they had no part in creating. Again, the Saunders case provides an example: the deed in that case was drawn up for Lee by a firm of solicitors with the aim of maximising the likelihood that Lee could obtain a loan from a building society. In contrast, in contracting party enforcer cases the enforcer will generally have created the document in question. Even in cases where the enforcer did not create the document, they have taken responsibility for it in the sense that they chose to put it forward as an offer for the signer to accept by signature.

\section{Significance of these differences}

The first two differences are that contracting party enforcers have a stronger moral claim and a different legal basis for expecting the signer to conform with the document in question. Rather than being mere third parties to the deed in question, contracting party enforcers have themselves been prepared to take on legal obligations with respect to the signer and as a result have a right to expect contractual performance. It is a fundamental mischaracterisation of a contracting party enforcer's claim to treat them in the same way as an innocent third party relying on an apparently valid signature.

Furthermore, it is also a fundamental mischaracterisation of a contracting party enforcer to treat them as equivalent to a bystander to the deed who encounters the document after it has been executed. A contracting party enforcer will not only have interacted with the signer prior to the signature but will be responsible for the contents of the document. A contracting party enforcer is not a third party; they are a vital participant in the process of contract formation. Arguably, with that role in contract formation come consequences that do not apply to innocent third parties as a rule. First, an opportunity to interact with the signer means that, in every case, a contracting party enforcer had some opportunity to be alerted to any issues with the signer's capacity prior to the signature. Secondly, because a contracting party enforcer prepared the contractual document, this gives them greater control over the signer's impression of the document than a third party enforcer. This control could count for or against a contracting party enforcer's claim to enforce the contract. Arguably, a contracting party enforcer who has written a contract that is needlessly confusing and requires the signer to seek explanation from someone else bears some of the responsibility if the signer receives an erroneous explanation. On the other hand, perhaps a contracting party who has 
prepared a comparatively clear document should not be penalised if the signer is provided an erroneous explanation.

The consequences of these differences are as follows. First of all, accepting the premise that innocent third parties deserve protection does not lead to the conclusion that contracting parties also deserve protection, because contracting parties are not innocent third parties. The compromise explanation thus fails to give us a reason for why non est factum applies to contracting parties. One response to this might be to adapt the compromise explanation and say that we would expect the law to strike a balance between:

- the protection of contracting parties who rely on the validity of apparently legitimate signed contracts; and

- the desire to provide relief to signers who did not actually intend the contracts that they sign.

The problem with this manoeuver is that there is no obvious reason why the compromise point between those two policies happens to be the exact same point between the two policies in the original compromise explanation. That might be the case but, again, because the compromise explanation is focused on third parties, it does not give us a reason to think so. Indeed, the differences between third parties and contracting parties might lead us to expect that, compared to third parties, contracting parties deserve greater protection (because of their stronger moral claim and different legal claim) but are also held to a higher standard (because they have played a greater role in the signing of the document). ${ }^{37}$

This leaves us with the conclusion that the traditional explanations for non est factum do not give us a contract law explanation for non est factum. So, the search must continue.

\section{Chen-Wishart's Institution of Contracting Argument}

\section{Chen-Wishart's argument}

Chen-Wishart provides what is, to my knowledge, the only developed attempt to explain why non est factum applies to contract law in terms of contract law thinking as opposed to the compromise explanation. ${ }^{38}$ Her explanation of non est factum is part of a valuable discussion of the operation of objectivity in contract law. Chen-Wishart argues that: ${ }^{39}$

37 The contract law explanation of non est factum I provide essentially does both those things. I suggest that contracting party enforcers are given greater protection and held to a higher standard by allowing a contracting party signer to plead non est factum for trickery only if the enforcer is responsible for, or aware of, the trickery: see below at Part III.C.3: Trickery.

38 Lee Mason argues that, while some cases where non est factum may succeed could be addressed by other remedies, non est factum should survive to do justice in those rare occasions where no other remedy is available. However, there is no development of the conception of justice that justifies non est factum in those residual cases, or how it applies to contracts: see Lee Mason "The Narrow Doctrine of Non Est 
... one of contract law's primary functions is to protect the facilitative institution of contracting. That is, "to protect both the practice of undertaking voluntary obligations and the individuals who rely on that practice ... One protects the practice of undertaking voluntary obligations by preventing its erosion - by making good any harm caused by its use or abuse." The objective principle prevents people from abusing the practice of contracting by making it appear that they have agreed to obligations when they have not. ... Liability is not imposed to protect voluntariness on the individual level (except at the very high threshold level of non est factum), but in order to protect the practice of undertaking voluntary obligations; to preserve its appeal and utility.

$\ldots$

Paradoxically, it is in order to protect the practice of contracting from debasement that the law recognises the validity of contracts that are not voluntary obligations.

As Chen-Wishart argues, if a written contract were to be void merely because the will of one of the parties does not correspond with its contents (which is what the consent explanation for non est factum might have one think), then that might be good for the autonomy of that individual but would ultimately undermine the autonomy-promoting institution of contracting. As a result, contract law is prepared to enforce contracts even when one of the parties actually intended something else. To this end, Chen-Wishart argues, contract law generally approaches questions of contract formation and construction from an observer-contextual viewpoint. ${ }^{40}$ The observer aspect of that viewpoint means that contract law considers what an observer would interpret a party's conduct as meaning (in contrast with an actor viewpoint which considers things from the point of view of the speaker rather than the listener). ${ }^{41}$ The contextual aspect means that the observer takes a contextual approach to interpretation, rather than a literal one that gives undue weight to formal pronouncements of intent. ${ }^{42}$

For Chen-Wishart, non est factum is an exception to that general observer-contextual approach. The reason Chen-Wishart gives for this exceptional switch is as follows: ${ }^{43}$

Factum Under English Common Law: A Declining, but not Defunct, Defence for Mistakenly Signed Documents" (2014) 20 Comparative Law Journal of the Pacific 113. As Rex Ahdar argues, this kind of leaving open of the door for individualised justice is out of step with contract law's traditional emphasis on certainty: see Rex Ahdar "Contract Doctrine, Predictability and the Nebulous Exception" (2014) 73 CLJ 39.

39 Chen-Wishart, above n 19, at 347-348. In this passage, Chen-Wishart cites J Raz "Promises in Morality and Law" (1982) 95 Harv L Rev 916 at 937.

40 Chen-Wishart, above n 19 , at 350.

41 At 349

42 At 351-354.

43 At 364-365. 
... while contract law aims to facilitate the autonomy-enhancing institution of contract by preventing its abuse (hence observer-objectivity which safeguards voluntariness at the institutional level), contract law cares about autonomy at the individual level and hence actor-objectivity, to [the extent reflected in non est factum].

... the idea is that a contract law which enforces voluntarily assumed obligations should, at least, accept that a party who is so fundamentally mistaken about the gist, or core, or substance of what he or she has undertaken (he or she is not even in the right "ball park") has not really undertaken anything. Phrased differently, you need not actually agree to every rule of the club to be bound by them, but you must at least have joined the right club.

For Chen-Wishart, the underlying reason for why contract law releases a signer who successfully pleads non est factum is the same as why contract law binds a signer who fails to make out the requirements of the plea: it is for the good of the institution of contracting. The signer who carelessly leads an enforcer to reasonably believe that they have agreed to the enforcer's terms ought to, for the good of the institution of contracting, accept that they are bound to terms they did not actually intend. Similarly, an enforcer who discovers that the signer, without carelessness, signed the contract because of a flawed explanation, ought to, for the good of the institution of contracting, give up enforcing the document despite the fact that this means losing out on a bargain they reasonably expected. It is contract law's job, as protector of the institution of contracting, to ensure that parties comply with what they ought to do for the good of that institution. Chen-Wishart's explanation of non est factum could thus be summarised as follows:

Non est factum voids a contract when a signer has made a fundamental mistake about the nature of the obligation that was reasonable for them to have made under their circumstances. The rationale for this is that voiding a contract under such circumstances promotes individual autonomy and the institution of contracting better than upholding a contract.

\section{Critique of Chen-Wishart's argument}

Chen-Wishart's argument ticks boxes (1), (2) and (3) in my list of features of an ideal contract law explanation of non est factum: it gives an explanation of why non est factum applies to contracts, and it is not inconsistent with contract law doctrine or thinking. However, Chen-Wishart's argument falls short on the fourth feature in that her argument does not provide a clear explanation for the specific features of non est factum. It does explain some aspects of the specifics of non est factum. It explains why the result of a successful plea is that the contract is void - because in a successful case of non est factum, no contract has formed. Chen-Wishart's account also explains the focus on whether the signer took reasonable care - this is because, even though non est factum switches from the usual observer viewpoint to the actor viewpoint, requiring the signer to have taken reasonable care means that the test is still objective. Chen-Wishart also explains the requirement for the mistake to be fundamental - for contract law to hold a party to a contract they 
are fundamentally mistaken about would be detrimental to the practice of contracting, but so would relieving a party from contractual obligations for anything less than a fundamental mistake.

However, Chen-Wishart's explanation of non est factum does not make it clear why the plea of non est factum requires that the signer has been misled by some explainer into holding their mistaken view of the document, or what is important about incapacity or trickery. Perhaps it is implicit that these requirements for non est factum are an account of the circumstances under which it is reasonable to have made a fundamental mistake about the nature of the obligation. Or it could be that incapacity and trickery require special responses in terms of protecting the institution. The reasoning for these features on Chen-Wishart's account is not made clear.

\section{My Contract Law Explanation of Non Est Factum}

My contract law explanation of non est factum has a number of things in common with ChenWishart's. My approach also explains the result of non est factum, that the contract is void, in terms of a lack of contract formation. I agree with Chen-Wishart that non est factum can be explained in terms of contract law's role as protector of the institution of contracting through objective assessment of contract formation. However, rather than suggesting non est factum is a special principle that requires an exceptional inquiry at the actor level, I see non est factum as an unexceptional application of the objective principle in Smith $v$ Hughes. To make that argument, I will first set out that objective principle before explaining how it applies to non est factum.

\section{Smith v Hughes objectivity}

In Smith v Hughes, Blackburn J gave an exposition of how to address cases where one party actually intended to contract on one set of terms and the other party actually intended to contract on a different set of terms. Non est factum cases will always fall into that pattern, since the signer thought that the contract was on one set of terms (based on what the explainer told them) and the enforcer thought that the contract was on a different set of terms (those set out in the contract). Blackburn J stated that, in such a case: ${ }^{44}$

... there is no contract, unless the circumstances are such as to preclude one of the parties from denying that he has agreed to the terms of the other [which is the case when:] ... If, whatever a man's real intention may be, he so conducts himself that a reasonable man would believe that he was assenting to the terms proposed by the other party, and that other party upon that belief enters into the contract with him, the man thus conducting himself would be equally bound as if he had intended to agree to the other party's terms.

So, according to Smith $v$ Hughes, in a case where a signer claims non est factum and the court accepts that the signer did not intend the same terms as the enforcer, a contract will have formed

44 Smith v Hughes, above n 12, at 607. 
only if the enforcer can establish that the facts fall within the scenario described in Blackburn J's famous dicta set out in the latter part of the above paragraph. I will refer to this as the "reasonably led" scenario.

Since the reasonably led scenario is the only way for a contract to form when the parties intended different terms, it is worth paying close attention to what is required. ${ }^{45}$ There are two perspectives that we need to consider with respect to each party: what the party actually thought the terms of the contract were, and what a reasonable person in the party's shoes would have thought the terms of the contract were. For a party A, I will use A to refer to A's terms and r(A) to refer to the terms that a reasonable person in A's position would have thought the contract incorporated. Considering $\mathrm{r}(\mathrm{A})$ essentially means imagining a reasonable person in A's shoes asking, "What am I giving the impression that we have agreed to, based on what I have said and done and what the other party has said and done?" In a case where the signer argues non est factum, we know that the parties had different ideas of the terms of the contract:

\begin{tabular}{|l|l|}
\hline Signer & Enforcer \\
\hline $\mathrm{X}$ & $\mathrm{Y}$ \\
\hline
\end{tabular}

When, then, will the contract be enforceable despite the lack of actual consensus ad idem? According to Smith $v$ Hughes, it will be enforceable only in the following scenario:

\begin{tabular}{|l|l|l|l|l|l|}
\hline Scenario & Signer & r(Signer) & Enforcer & r(Enforcer) & Outcome \\
\hline Reasonably led & $\mathrm{X}$ & $\mathrm{Y}$ & $\mathrm{Y}$ & $\mathrm{Y}$ & Contract $\mathrm{Y}$ \\
\hline
\end{tabular}

In contrast, there would be no contract in either of the following scenarios: ${ }^{46}$

\begin{tabular}{|l|l|l|l|l|l|}
\hline Scenario & Signer & r(Signer) & Enforcer & r(Enforcer) & Outcome \\
\hline $\begin{array}{l}\text { Both } \\
\text { unreasonable }\end{array}$ & $\mathrm{X}$ & Not X & $\mathrm{Y}$ & Not Y & No contract \\
\hline $\begin{array}{l}\text { Reasonable but } \\
\text { different }\end{array}$ & $\mathrm{X}$ & $\mathrm{X}$ & $\mathrm{Y}$ & $\mathrm{Y}$ & No contract \\
\hline
\end{tabular}

45 My analysis here draws upon JR Spencer "Signature, Consent, and the Rule in L'Estrange v Graucob" (1973) 32 CLJ 104; William Howarth "The Meaning of Objectivity in Contract" (1984) 100 LQR 265; JP Vorster "A Comment on the Meaning of Objectivity in Contract" (1987) 103 LQR 274 at 276; ChenWishart, above n 19; David McLauchlan "Objectivity in Contract" (2005) 24 UQLJ 479 at 482 ; David McLauchlan "Contract Interpretation: What is it About?" (2009) 31 Syd LR 5; and David McLauchlan "Refining Rectification" (2014) 130 LQR 83.

46 See Vorster, above n 45, at 286. 
As to why a contract has formed on the enforcer's terms only in the reasonably led scenario, we can explain this in terms of contract law's protection of the autonomy-enhancing institution of contracting. As Chen-Wishart says, contract law cares about individual autonomy, and enforcing a contract contrary to the intentions of one of the parties detracts from their autonomy. But, contract law cares about the autonomy of both parties. As a result, that one party did not intend the terms of a written contract is not a sufficient ground to conclude that there is no contract. That would be a unilateral prioritisation of one party's autonomy that is incompatible with the bilateral nature of contracting and contract law. On the other hand, that one party did intend the terms of a written contract that the other signed is not sufficient grounds to conclude that there is a contract either, for the same reason. ${ }^{47}$ The reasonably led scenario represents the point where one party has a morally overwhelming claim for the formation of a contract on their terms. This is because the enforcer's terms would have been the same terms expected by a reasonable person in the enforcer's position. However, the same cannot be said for the signer. In the reasonably led scenario, a reasonable person in the signer's shoes would not have expected a contract on the same terms as the signer, and indeed would have expected a contract on the enforcer's terms. As a result, that is the case when contract law will, contrary to the intentions of the signer, find that a contract has formed on the terms of the signer.

In contrast, in the other two scenarios described above, where there is no contract, the enforcer does not have a compelling stronger claim for the formation of a contract on their terms. In the "both unreasonable" scenario, neither party's terms would have been shared by a reasonable person in their position, so neither has a moral claim for a contract on their terms. In the "reasonable but different" scenario, both party's expected terms would have been the terms a reasonable person in their position expected. As a result, neither party has a stronger moral claim to the enforcement of a contract on their terms, so there is no contract. As a potential example of that sort of scenario, Howarth gives The Peerless, the classic contract law case where the parties signed a contract for goods to be delivered on a ship the Peerless, but both had a different Peerless in mind. ${ }^{48}$ If each party's expectation of a contract regarding their Peerless was reasonable based on their individual knowledge, then we can explain the outcome that there is no contract in terms of Smith v Hughes. As The Peerless example illustrates, differences between $\mathrm{r}$ (signer) and $\mathrm{r}$ (enforcer) arise because the parties did not have access to the same information. This is vital for understanding non est factum as an application of Smith $v$ Hughes.

47 Of course, that one party did intend the terms of a written contract and the other signed it goes a long way towards establishing that there is a contract, but it is not sufficient.

48 Raffles $v$ Wichelhaus (1864) 2 H\&C 906 (Exch) [The Peerless]. 


\section{Incapacity non est factum and objectivity}

Non est factum involving incapacity can be explained as a particular instance of the reasonable but different scenario. The explanation is fairly straightforward: a successful case of non est factum is one where signer=r(signer) and, even though the enforcer may have had a reasonable expectation of a contract on their terms (that is enforcer=r(enforcer)), no contract forms because the enforcer does not have a better claim than the signer does. Another way of explaining this is to say that non est factum is not an example of the reasonably led scenario, and a reasonable person in the signer's position would not have to accept that, for the good of the institution of contracting, there is a contract on the enforcer's terms.

This explanation of non est factum is, I would suggest, a good fit for the features of the doctrine. It explains the emphasis on incapacity. Incapacity clearly establishes that the signer and enforcer have access to different information - it is simply not possible for the signer to have a full understanding of the contents of the document. This allows for the possibility that signer $=r($ signer $)=X$ while enforcer $=r($ enforcer $)=Y$. Furthermore, incapacity introduces the need for an explainer, because the signer's lack of capacity means they have to rely on someone else. This fits with non est factum's traditional focus on an erroneous explanation. My explanation also tells us why the care taken by the signer has always been a key part of the assessment of non est factum. This is because if the signer has been careless then signer $\neq r($ signer) and the signer has lost the ability to claim that they are in the reasonable but different scenario. Finally, it also explains why non est factum is concerned with fundamental mistakes. A reasonable person in the position of the signer would have to take into account that (i) they have chosen to sign a document without being able to fully appreciate its contents and (ii) their understanding of the contract is based on the explainer's explanation. Under those circumstances, it would not be reasonable to demand that a contract forms only if the explanation is correct about every last detail. A reasonable person in the position of the signer would consider themselves to have assented to the gist of the explanation, not the letter. Accordingly, it is only if the explanation was fundamentally flawed that agreement is lacking.

My explanation for non est factum thus far works for cases of incapacity, but I have not yet offered an explanation for understandings of the doctrine that hold either that trickery is an alternative to incapacity, or that incapacity is not actually a requirement.

\section{Trickery}

Cases where there is trickery (and here I am taking trickery broadly to include inept explanations as well as deliberately fraudulent ones) that the enforcer is responsible for, actually aware of, or ought to have been aware of, are fairly simple to explain. These are cases where a reasonable person in the enforcer's shoes would not have grounds for expecting a contract on their terms. As a result, the facts do not fall within the reasonably led scenario, and there is no contract. The reasonably led scenario requires not only assessing whether a reasonable person in the signer's 
shoes would have accepted that they gave the impression of a contract on the enforcer's terms, but also whether a reasonable person in the enforcer's shoes would have thought that the signer was actually assenting to the enforcer's terms. In addition, if the enforcer is responsible for (as opposed to merely aware of) the signer's mistake (for example, because the explainer is their agent), then one can argue that there is no enforceable contract on the basis of Curtis $v$ The Chemical Cleaning and Dyeing Co Ltd or Scriven Bros v Hindley \& Co ${ }^{49}$ That the enforcer interacts with the signer and is responsible for the document in contract cases opens up the possibility of these sorts of arguments. In contract cases, the signer thus has additional escape routes available, but only if the enforcer has a connection to their mistake. ${ }^{50}$ In cases of persons of capacity who have been tricked, it thus makes sense to take a close look at the enforcer rather than focusing on the signer. ${ }^{51}$

But what of the cases where the enforcer is entirely innocent with respect to trickery that has been conducted by some unconnected explainer? In my view, if the case is a contract case, the signer should be out of luck and the enforcer should have their contract. ${ }^{52}$ This is because, compared to an innocent third party, the enforcer has a strong moral and legal claim for enforcement. A signer of capacity who is, for example, the victim of a third party fraudster or the recipient of poor advice from their trusted advisor might be, in a sense, innocent, but is not as innocent as the enforcer. In contract cases, the close and necessary connection between signer and enforcer means that the signer has arguments against contract formation that are not available in true innocent third party cases. The counterbalance to this is that the absence of any fault on the enforcer's part should count against the signer's attempt to escape enforcement.

\section{No formal requirement for incapacity or trickery}

Earlier, I argued that incapacity non est factum is explicable as a case of the reasonable but different scenario that results in no contract under Smith v Hughes. Broadly speaking, the same argument can be made if non est factum has no formal requirement for incapacity or trickery. That said, I would suggest that my explanation of non est factum is a better fit for the version of non est factum that does require incapacity or trickery. This is because incapacity plays a vital role in my explanation of non est factum and its features.

49 Curtis $v$ The Chemical Cleaning and Dyeing Co Ltd [1951] 1 KB 805 (CA), where there was a misrepresentation by the enforcer about the contents of the contract; and Scriven Bros $v$ Hindley \& Co [1913] 3 KB 564 (KB), where there was no contract because the signer's confusion was the result of the enforcer's confusing documentation.

50 See Bradley West, above n 20, at 118; and Petelin v Cullen, above n 18, at 360.

51 See also Bradley West at 119.

52 Support for this proposition can be found in Petelin v Cullen, above n 18, at 360; and Lloyds Bank plc v Waterhouse [1993] 2 FLR 97 (CA) at 117 and 122-123. 


\section{CONCLUSION}

Non est factum is not out of place in contract law after all. Successful cases of non est factum can be explained as being a subset of the cases where there is no contract according to the objective principle set out by Blackburn $\mathrm{J}$ in Smith $v$ Hughes. Non est factum, in the contract law context, is arguably not a special doctrine that makes exceptional inquiries but is no more than a particular instance of the reasonable but different scenario which Smith $v$ Hughes tells us does not result in contract formation. Seen this way, non est factum does not require any special justification - it is simply a manifestation of how contract law resolves disputes between parties with conflicting intentions. Furthermore, it is not anomalous, since the results can be seen as consistent with contract law doctrine and thinking. It is not a unilateral inquiry, because the Smith v Hughes assessment of contract formation considers the actual intentions of both parties (as well as what reasonable persons in their shoes would have understood).

For the most part, accepting my account of non est factum does no more than provide a more satisfactory explanation of why non est factum applies to contracts. However, there is one respect in which it perhaps has some bite. My explanation suggests that the best way of understanding non est factum is that there is a requirement for either incapacity or trickery. In addition, trickery will not be a sufficient reason to set aside a signature if the enforcer has no knowledge of, or responsibility for, the incorrect explanation relied upon by the signer. 
